Masarykova univerzita, Brno

tuskova@ped.muni.cz

\title{
K POPISU GRAMATICKÉ STRÁNKY PROPRIÍ V ČEŠTINĚ
}

Klíč o vá s lova: onomastická gramatika, gramatické vlastnosti proprií, morfologická stránka proprií, komunikační varianty

Vztah onomastiky a gramatiky je předmětem obecně onomastických výzkumů až od 60.-70. let 20. století a na přelomu 20. a 21. století přerostl v novou subdisciplínu onomastiky - onomastickou gramatiku. K předmětu onomastické gramatiky se vyjadřuje řada autorů světové onomastiky, jejich názory se však různí výchozími stanovisky, viz např. Eichler et al. 1995: 400-408 nebo Šrámek 1999c: 121-127; 2007a: 501-511. Z tohoto důvodu ještě nebyla podána všeobecně přijímaná definice. Jedna z možných je obecná definice R. Šrámka, v níž se odráží funkční pohled na propria:

Předmětem onomastické gramatiky jsou všechny jazykové, jazykově komunikační a mimojazykové elementy, jevy a kategorie, které slouží ke vzniku, uspořádání a fungování propriální sféry jazyka. Onomastická gramatika jako subdisciplína onomastiky se zabývá studiem (popisem, analýzou, typologií, kategorizací) konečné množiny jazykových a nejazykových elementů, které jsou strukturovány jako svébytný systém a prosazují se jak v propriálně pojmenovacím aktu, tak v komunikačním užití proprií podle určitých schémat majících noremní charakter (1999c: 126-127).

V 90. letech 20. století sice ve světě vzniklo několik onomastických gramatik, ty se však navzájem podstatně liší po stránce teoretické, metodologické i obsahové, a tak odrážejí dosud nestabilizované a podrobněji nepropracované názory na cíle onomastické gramatiky a jsou spíše obrazem různého chápání onomastiky vůbec. Jedná se o onomastickou gramatiku francouzštiny Grammaire du nom propre (Gary-Prieur 1994), norštiny Imja sobstvennoe v sovremennom norvežskom jazyke. Grammatičeskij očerk (Aljokšina 1997) a rumunštiny Gramatica numelor proprii în limba românâ (Tomescu 1998). Z uvedených děl je třeba vyzvednout onomastickou gramatiku rumunštiny, která jako první podává ucelený a systematický pohled na ty vlastnosti proprií, které mají gramatický příznak, přičemž vychází důsledně z formy vlastních jmen. Autorka se inspiruje románskou gramatickou tradicí a spojuje ji s díly obecné lingvistiky. V Česku se teoretickým základům onomastické gramatiky dosud věnovali zejména R. Šrámek (1999a, b, c; 2007a) a M. Harvalík (2006a, b). 
Odhlédneme-li od specifik jednotlivých evropských jazyků promítajících se do gramatické stránky proprí, lze říci, že popis gramatických vlastností proprií byl dosud: 1) tradičně redukován na pouhý slovotvorný mechanismus. Ten je však v našem pojetí onomastiky integrální složkou názvotvorného ${ }^{1}$ procesu, nebot' se týká způsobů jazykového zpracování proprií, zvláště na úrovni motivační; 2) chápán jen jako soubor diferencí od apelativ, tzn. gramatické vlastnosti proprií se popisovaly v kontextu gramatických vlastností apelativ. Kontrastivní analýza apelativ a proprií by měla být jedním z kroků popisu, ne však jeho konečným cílem, nebot' hodnoticí kritéria bývají obvykle přenesena z formálních vlastností apelativ; 3) méně často vymezována speciálními morfologickými (paradigmatickými), řidčeji syntaktickými vlastnostmi proprií; 4) k problematice gramatiky vlastních jmen bývají někdy prriřazovány také informace o jejich grafické či ortografické stránce (zvl. v onomastice německé).

S ohledem na specifické funkce proprií (individualizační, diferenciační a lokalizační) a na jejich postavení v jazyce (propria tvoří tzv. druhou vrstvu jazyka) by se podle R. Šrámka (1999c: 126) mělo stát východiskem české onomastické gramatiky funkční a systémové pojetí proprií, nikoli jen redukce na slovotvorné jevy. Při formulování onomastické gramatiky by mělo být klíčovým faktem to, že na úrovni propriálních vlastností musí být zachován individualizační vztah propria k onymickému objektu. Avšak v okamžiku zařazení propria do komunikace vzniká tlak, pod jehož vlivem je vlastní jméno nuceno přizpůsobovat se gramatickým zákonitostem apelativní sféry jazyka. Míra tohoto přizpůsobení může být u jednotlivých tř́́d proprií odlišná (Tušková 2011a: 52), např. některé skupiny oikonym mají tendenci udržovat si pro ně typické tvary Chrudimi/Chrudimè2.

Do Chrudimi a Slatiňan vyjede historický motoráček, a to hned dvakrát (SYN2015, PUB) ${ }^{3}$.

Mladí lidé s radostí pomáhali nejen v ulicích Chrudimě (SYN2015, PUB).

${ }^{1} \mathrm{~V}$ onomastické literatuře se rozlišují termíny slovotvorba a názvotvorba. Termín nazwotwórstwo = názvotvorba, který navrhl polský onomastik H. Borek, je obsahově širší, protože zahrnuje i zřetele motivační. Pojem slovotvorba zužuje pohled na propria, a to především na jejich slovotvornou strukturu, která je pro určení vzorových jmen výhodnější, nebot' se týká morfémového složení slova = vlastního jména a nikoli jeho vlastností jako propria.

${ }^{2} \mathrm{U}$ femininních oikonym zakončených na - $m$ v současné spisovné češtině převažuje v genitivu singuláru historicky mladší koncovka -i, viz materiál korpusů SYN2015, SYN2010, SYN2005, SYN2000. Podle výzkumů v korpusu SYN2000, viz Tušková (2007), existuje kolísání v př́ípadě oikonym na -m pouze u jmen domácích, jména cizí, zčásti slovanská, např. polská Radom, Bytom, či neslovanské Bochum, mají pravidelné tvary vz. kost, tzn. v Gsg. jen koncovku $-i$.

${ }_{3}^{3}$ Př́iklady tvarů proprií byly vyhledávány $\mathrm{v}$ nejnovějším synchronním korpusu psané češtiny SYN2015. Korpus obsahuje 100 milionů textových slov a navazuje na předchozí korpusy řady SYN. Obsahuje především texty z let 2010-2014 a jedná se o jazyk tištěný a veřejně publikovaný. V korpusu jsou rovnoměrně zastoupeny tři hlavní textové makrotypy: beletrie 33,33\%, odborná literatura 33,33\% a publicistika 33,33\%. Typy textů jsou označeny zavedenými zkratkami, např. PUB — publicistika, POP — populárně naučná literatura. Podrobněji viz http://www.korpus.cz 
Pro chrématonyma vzniklá transonymizací je však naopak př́iznačné přizpůsobení se apelativní deklinaci: pouze tvar Chrudimi (jako vz. kost - Gsg. kosti).

Zpočátku byl rád za každou šanci, dokonce vypomáhal i prvoligové Chrudimi (SYN2015, PUB).

Tlak propriální vrstvy na apelativní existuje, ale jeví se jako sekundární. Při nominaci se tedy určitý konkrétní neopakovatelný prvek nějakého souboru pojmenovává s poukazem na jeho singulativnost a př́i tomto procesu získávají propria vždy podobu substantiva (Uhřiněves, Nejezchleb, Tenkrát, Veselý). Ta potom při komunikaci podléhá morfologickým a syntaktickým zákonitostem daného jazyka. Z tohoto hlediska je onomastická gramatika sice zakotvena v apelativní sféře a v pravidlech tvoření výpovědi, ale vznik propria, tj. akt nominace, je vlastností propriální sféry jazyka (Tušková 2011a: 52). Podle R. Šrámka (1999c: 126) by se onomastická gramatika měla věnovat primárně na obecné úrovni popisu principů propriální nominace, tj. propojení studia a popisu vztahu mezi kategoriemi propriálně pojmenovací motiv a jeho jazykové ztvárnění ve vlastní jméno (popis etymologicko-lexikální a názvotvorně-morfémové složky proprií), dále pak charakteristice těch gramatických (morfologických, paradigmatických aj.) a stylistických jevů, které vyplývají ze začlenění proprií do komunikačních aktů a textů.

Zaměřme se nyní úžeji na oblast popisu gramatických jevů proprií $\mathrm{v}$ če štině, a to především na příkladech standardizovaných (úředních) ${ }^{4}$ podob oikonym. Důležité postavení má v tomto popisu oblast morfologických vlastností proprií.

Na úvod konstatujme, že komplexní popis gramatických jevů proprií češtiny pro účely onomastické gramatiky i pro porovnání s morfologií apelativ nebyl dosud zpracován. Prozkoumanost morfologických vlastností proprií je v češtině u jednotlivých tříd proprií různá. $\mathrm{V}$ gramatikách současné češtiny, např. v České mluvnici (Havránek, Jedlička 1981), Mluvnici češtiny 2 (Petr (red.) 1986), Př́ruční mluvnici češtiny (Grepl et al. 1995), Mluvnici současné češtiny 1 (Cvrček et al. 2010), Akademické gramatice spisovné češtiny (Šticha et al. 2013), najdeme neúplné popisy deklinace vlastních jmen zaměřené téměř výhradně na deklinaci vybraných skupin domácích a cizích toponym a antroponym. Problematice gramatických kategorií proprií se pak v ucelené kapitole věnuje pouze Mluvnice češtiny 2. Při popisu deklinace vycházejí mluvnice primárně z apelativní vrstvy jazyka, což se projevuje i v tradičním začlenění popisu deklinace proprií do popisu de-

${ }^{4}$ Závěry našich výzkumů oikonym vycházejí z materiálů psaných korpusů češtiny: SYN2000, SYN2005, SYN2010, které obsahují především standardizované podoby oikonym. Variantnost tvarů oikonym je ve standardizované podobě menší než v podobách neúředních, které u mnohých oikonym v češtině existují a často pocházejí z místního nářečního úzu, např. Olomouc (spis. femininum) Olomouc (nár. maskulinum) (Balhar et al. 2002: 68). 
klinace apelativ, viz Česká mluvnice, Mluvnice češtiny 1, Akademická gramatika současné češtiny. Výjimku tvoří alespoň částečně Mluvnice češtiny 2 a specificky Př́ruční mluvnice češtiny, kde jsou popisu deklinace proprií věnovány samostatné kapitoly působící však (zejména v Př́ruční mluvnici češtiny) jako dodatky k deklinaci apelativ. K popisu morfologické stránky proprií, opět především antroponym a toponym, pak existují četnější onomastické studie, avšak ojedinělé monografie. K místním jménům je to práce A. Polívkové (2007) zabývající se deklinací jmen větších míst, nověji a s využitím korpusů se morfologii oikonym věnuje monografie J. M. Tuškové (2011a), informace ke gramatické stránce antroponym najdeme v monografii M. Knappové (1989: 14-16). Oblast morfologické stránky chrématonym je popsaná zatím jen ojedinělými pracemi, např. J. Kornellyho (2006: 20-28).

Při popisu morfologických vlastností proprií v češtině je dle našeho názoru důležité zaměřit se na tyto oblasti: 1) specifické užití kategorií rodu, životnosti, čísla, pádu a 2) morfologická paradigmata (s ohledem na existenci jednoslovných i víceslovných podob vlastních jmen). Propria považujeme za vhodné rozdělit do tř́ základních onymických tříd (bionyma, geonyma, chrématonyma) $\mathrm{a}$ těm se pak věnovat zvlášt $t^{5}$. Ty pak ještě dále členit $-\mathrm{v}$ rámci tř́́dy bionym věnovat pozornost zejména antroponymům a $\mathrm{v}$ príípadě geonym hlavně toponymům (zde zvlášt' popsat oikonyma a anoikonyma). Je nutné zabývat se tím, co mají hlavní trrídy proprií společné a co rozdílné a mít na mysli fakt, že mezi nimi dochází k tzv. transonymizaci.

Specifika gramatických kategorií lze najít jak vodlišnostech jejich užití mezi apelativy a proprii, viz komplexně Mluvnice češtiny 2 (Petr (red.) 1986: 346-349), se zaměřením na vybrané třídy/skupiny proprií, např. J. M. Tušková (2011a: 53-55), J. Šimandl (2012a: 124-128), tak mezi jednotlivými tř́dami proprií.

Uved'me nyní, jaká specifika mají ve využití gramatických kategorií v oblasti spisovné češtiny oikonyma (šiřreji toponyma) oproti ostatním tř́dám proprií:

Oikonyma (šiřreji toponyma) mají své odlišnosti oproti ostatním třídám proprií v rámci kategorie čísla.

- Oikonyma (toponyma obecně) existují zpravidla jen jako singularia tantum (Brno, Olomouc atd.), nebo pluralia tantum (Luhačovice, Vinohrady atd.), zatímco převládajícím a bezpř́znakovým číslem u antroponym (Eva, Dvořák atd.) a chrématonym (Masarykova univerzita, Den matek atd.) je singulár.

- U některých oikonym tvary plurálu oproti singuláru získávají platnost onymických názvotvorných prostředků, např. Dvůr - Dvory.

Ve využití kategorie rodu, životnosti a pádu existují společné rysy u oikonym (šířeji toponym) a chrématonym oproti antroponymům.

5 Obdobné názory najdeme také u V. Blanára: „Úplnejší, ale aj diferencovanejší pohl’ad získame, ak budeme charakterizovat' morfologickú stránku vlastných mien ako prvkov rozličných onymických podsystémov samostatně“ (2005: 21). 
- Oikonyma (toponyma) a chrématonyma mají všechny tři gramatické rody, zatímco antroponyma jen rod mužský a ženskýb vycházející z přirozeného rodu, např. Mělník (m.), Praha (f.), Valašské Meziřicí (n); Dekret kutnohorský (m.), Česká filharmonie (f), Národní muzeum (n.) x Petr (m.), Marie (f.). Dá se tedy ř́íci, že antroponyma jsou více spjata s mimojazykovou realitou než toponyma a chrématonyma a využití všech tří rodů u toponym a chrématonym přibližuje tyto třídy proprií $\mathrm{k}$ apelativní sfére jazyka.

— U českých oikonym (šířjeji toponym) pozorujeme dlouhodobou tendenci k ženskému rodu, např. typy Boleslav, Olomouc (původně maskulina, dnes ve spisovné češtině feminina), typ Pardubice (dochází k ústupu mužských koncovek v některých pádech), viz Šimandl 2012a: 124.

- Oikonyma (toponyma) a chrématonyma jsou v převážné většině případů jen neživotná, např. Kolín; Starý zákon, zatímco antroponyma jsou jen životná, např. Pavel, Dvořák. Př́klady životných oikonym jsou v češtině vzácné, např. názvy vesnic v Čechách — Pohledští Dvořáci a Okrouhličtí Dvořáci, viz Profous 1947: 446.

- Oikonyma (toponyma) a chrématonyma zpravidla neužívají vokativ, zatímco u antroponym je běžný (Pavle, Martino). V případě oikonym se s vokativem setkáváme především v poetismech, nap̌r. Ostravo, Těšine (P. Bezruč).

— Případné další odlišnosti ve frekvenčním využití pádů u jednotlivých tříd proprií je třeba výzkumem ověřit.

Morfologická paradigmata proprií češtiny se typologicky nevymykají ze zákonitostí platných pro apelativní sféru jazyka, jež plní úlohu fundujícího východiska, mají však parasystémový charakter, a proto se vyznačují řadou tvarů (morfémů, grafémů) typických právě pro propria, např. u oikonym paradigmata typu Mělník (Gsg. Mělníka/Mělníku, Lsg. Mělníce/Mělníku), typu Přibram (Gsg. Př́brami/Přibramě), typu Koloděje (Gpl. Kolodějí/Kolodějů/Koloděj, Dpl. Kolodějím/Kolodějuom), podrobněji Tušková 2011a.

Palach se narodil ve V̌̌etatech, do školy začal chodit v Mělníce, [...] (SYN2015, POP).

Bude $v$ Mělníku Havlův most nebo náměstí? (SYN2015, PUB).

Poté nasedli do ministrova mercedesu a odjeli přes celou Prahu do Koloději (SYN2015, PUB).

Byl nalezen u Koloděj a Běchovic, jde o potvrzení starého údaje Čelakovského (SYN2015, POP).

Nositeli těchto jevů jsou především tzv. komunikační varianty proprií, viz níže. $\mathrm{V}$ rámci deklinace proprií lze proto předpokládat:

${ }^{6}$ V nespisovných nářečních projevech se $\mathrm{v}$ češtině můžeme setkat $\mathrm{u}$ antroponym (v oblasti rodných jmen) také s rodem středním, např. Anče.

7 Využití kategorie pádu se liší u jednotlivých tř́íd proprií i jinak než frekvenčně. Podle V. Blanára (2005: 31) jsou např. pro anoikonyma na rozdíl od antroponym typické předložkové útvary, které se neskloňují, ale vedle předložkové konstrukce někdy existuje bezpředložková podoba, která se dle potřeby sklon̆uje, např. Ve štrku - Štrki. 
— existenci samostatných deklinačních typů/podtypů u jednotlivých hlavních tříd proprií;

- rozdílné zastoupení toponym, antroponym a chrématonym $\mathrm{v}$ jednotlivých druzích deklinace, tj. jmenné a adjektivní.

Například při návrhu popisu deklinace femininních oikonym v češtině, který zachycuje psaný úzus současné češtiny, viz Tušková 2011a, bylo zjištěno sedm základních typů jmenné deklinace domácích oikonym ženského rodu (Ostrava, Bystřice, Třeboň, Uhřiněves, Pardubice, Nusle, Zahrádky), sedm jejich podtypů (Kaplice, Ǎs, Zliv, Př́bram, Vršovice, Kravaře, Koloděje) a jeden typ deklinace adjektivní (Blatná). U deklinace femininních apelativ, viz např. Př́ruční mluvnice češtiny (Grepl et al. 1995), se uvádějí tři deklinační typy jmenné (žena, růže, kost) a čtyři podtypy (skica, ruka, písě̌, ulice) a dva adjektivní typy podle typů mladý (pokojská atd.) a jarní (vedoucí atd.). Počet deklinačních typů a podtypů apelativ se však může v jednotlivých mluvnicích lišit. Základní typy deklinace femininních oikonym češtiny pak odpovídají v singuláru nebo plurálu typům a některým podtypům apelativního skloňování, např. typ Ostrava = typ žena, typ Bystřice = typ riǒže, typ Uhř́něves = typ kost, typ Nusle = typ růže , typ Třebon̆ = podtyp písěn. Podtypy femininních oikonym jsou však samostatné, v některých pádech obsahují tvary odlišné od deklinace apelativ. $\mathrm{Na}$ základě provedených výzkumů lze zobecnit, že se v deklinaci oikonym projevují dvě protichůdné a zároveň na sebe působící tendences: a) snaha manifestovat proprialitu oikonyma typickým tvarem či tvary v jejich paradigmatu; b) přizpůsobit v co největší míře deklinaci oikonym deklinaci apelativ, protože je to z hlediska potřeb účastníků komunikace výhodnější/ekonomičtější.

Při gramatickém popisu proprií by neměla zůstat stranou také jejich s y taktická stránka (funkce proprií ve větě nebo syntaktické konstrukce při tvorbě víceslovných vlastních jmen), viz např. Majtán 1988: 192. Syntaktické okolnosti plynoucí z pozice (funkce) propria ve výpovědi zůstávají však dosud v češtině stranou systematických onomastických výzkumů. V odborné literatuře - v některých mluvnicích češtiny a nečetných odborných studiích — najdeme většinou jen zmínky o syntaktické diferenciaci dubletních tvarů, např. u oikonym viz Př́ruční mluvnice češtiny (Grepl et al. 1995: 253), Tušková 2009: 226.

$\mathrm{V}$ souvislosti $\mathrm{s}$ fungováním proprií $\mathrm{v}$ komunikaci je třeba věnovat pozornost vzniku a fungování propriálně komunikačních variant nebo funkci proprií v různých typech textů. Jako komunikační varianty proprií jsou chápány takové formy proprií, jež vycházejí ze stejného základu jako základní (ofici-

${ }^{8}$ Tyto tendence uvádí v obecné rovině V. Blanár (2008: 9), když říká, že pro postavení proprií v jazykovém systému jsou charakteristické dvě tendence: „ustavičná interakcia vlastných mien s ostatnou slovnou zásobou a celým jazykovým systémom a zároveň stála polarizácia kategorie vlastných mien vo vzt’ahu k apelatívam“. Interakce VJ s ostatní slovní zásobou souvisí podle autora s procesy onymizace, apelativizace, otevřeností onymie a zvláště se společenskými potřebami komunikace. Polarizace VJ je dána specifickou povahou onymické nominace. 
ální) podoba jména, jsou ale obměněny hláskově, slovotvorně, paradigmaticky, gramatickým rodem nebo číslem (Harvalík 2006a: 194). Užití těchto variant je typické především pro mluvenou komunikaci realizovanou v hovorové formě spisovné češtiny, častěji v rámci projevů nespisovných. Setkáváme se s nimi v různé míře u všech druhů proprií, např. v oblasti rodných jmen (Anče, Hadámek, Liba), u nářečních přechýlených podob ženských př́ijmení (Novákula, Tomanka, Vráblena), u oikonym (rodové varianty m./f. u jmen typu Olomouc, Kroměřžz, zkracování víceslovných podob jmen Žd'ár nad Sázavou $\rightarrow$ Žd'ár nebo univerbizace náměstí Svobody $\rightarrow$ Svobod'ák), časté jsou komunikační varianty u anoikonym (týž objekt bývá pojmenován dvěma, zřídka třemi paralelně fungujícími jmény Pod duby - Poddubí, Pode hrázi - Podehrází - Na Podehrázi).

Při tvorbě navrženého gramatického popisu proprií češtiny by bylo tedy třeba všechny uvedené jevy zpracovat na rozsáhlém komplexu jednotlivých hlavních tříd proprií (bionyma, geonyma, chrématonyma), které jsou dále vnitřně členěny a liší se výběrem jazykovým prostředků. Je tedy nutné zabývat se tím, co mají tyto hlavní třídy společné a co rozdílné a věnovat pozornost také tzv. transonymizaci, k níž mezi nimi dochází (hydronymum Opava $\rightarrow$ oikonymum Opava $\rightarrow$ chrématonymum „,hotel“ Opava; oikonymum České Budějovice $\rightarrow$ chrématonymum „sportovní klub“ České Budějovice/Budějovice) a která rovněž ovlivňuje volbu jazykových prostř̌edků, viz Šrámek 2007b nebo Tušková 2012. Neméně důležitou otázkou k řešení jsou rovněž materiálové zdroje, z nichž by popis gramatické stránky proprií vycházel, a s tím spojený způsob popisu. Při dřívějším popisu proprií v mluvnicích byl východiskem minulý stav a předmětem popisu jeho současné změny, zvl. Mluvnice spisovné češtiny (Trávníček 1951), ve druhé polovině 20. století se mluvnické popisy více soustředily na současný stav, ale stále zpracovávaly materiálově omezené zdroje, v současnosti vycházejí české mluvnice a některé onomastické studie z dat o úzu, které nám ve velkém rozsahu poskytují korpusy. Při práci s korpusovým materiálem se však objevují také nové otázky, např. Co je z korpusových dat pro popis proprií relevantní? Zaměřit se na frekvenčně silné jevy a rezignovat na jevy nízkofrekvenční? Jak nejlépe vyhledávat tvary jednotlivých tř́d proprií?, podrobněji Šimandl 2012b nebo Tušková 2011b.

Vytvoření onomastické gramatiky češtiny by byl jistě úkol nelehký a časově náročný. Její existence by však umožnila komplexní pohled na problematiku gramatických jevů proprií. Jejím prostřednictvím bychom mohli prozkoumat uplatnění obecných gramatických zákonitostí ve sfére proprií a upozornit na jevy typicky propriální. 


\section{LITERATURA}

Aljokšina M. L. 1997: Imja sobstvennoe v sovremennom norvežskom jazyke. Grammatičeskij očerk, Evropejskij Dom, Sankt-Peterburg.

Balhar J. et al. 2002: Český jazykový atlas, 4, Academia, Praha.

Blanár V. 2005: Morfologické kategórie vlastných mien, [v:] J. Kačala (red.), Jazykové kategórie v teórii a praxi. Zborník statí, Univerzita Komenského, Bratislava, s. 21-52.

Blanár V. 2008: Vlastné meno vo svetle teoretickej onomastiky, Slovenská jazykovedná spoločnost' při SAV a Jazykovedný ústav L'udovíta Štúra SAV, Bratislava.

Cvrček V. et al. 2010: Mluvnice současné češtiny 1. Jak se píše a mluví, Univerzita Karlova, Praha.

Eichler E. et al. (eds.) 1995: Namenforschung. Ein internationales Handbuch zur Onomastik, 1. Teilband, Walter de Gruyter, Berlin-New York.

Gary-Prieur M.-N. 1994: Grammaire du nom propre, Presses Universitaires de France, Paris.

Grepl M. et al. 1995: Př́ruční mluvnice češtiny, Nakladatelství Lidové noviny, Praha.

Harvalík M. 2006a: Komunikační varianty vlastních jmen a jejich místo v onomastické gramatice češtiny, [v:] K. Rymut et al. (red.), Munuscula linguistica in honorem Alexandrae Cieślikowa oblata, Wyd. IJP PAN, Kraków, s. 193-200.

Harvalík M. 2006b: Dialectal Forms of Proper Names in the Onomastic Grammar of Czech, [v:] A. Timuška et al. (red.), Proceedings of the 4th International Congress of Dialectologists and Geolinguists. Riga, July 28-August 2, 2003, Latvian Language Institute, University of Latvia, Rīga, s. 216-220.

Havránek B., Jedlička, A. 1981: Česká mluvnice, Státní pedagogické nakladatelství, Praha.

Knappová M. 1989: Rodné jméno v jazyce a společnosti, Academia, Praha.

Kornelly J. 2006: Chrématonyma českých a moravských vín, Gaudeamus, Hradec Králové.

Majtán M. 1988: Gramatická stránka vlastného mena, [v:] K. Zierhoffer (red.), V Ogólnopolska Konferencja Onomastyczna, Wyd. Naukowe UAM, Poznań, s. 191-195.

Petr J. (red.) 1986: Mluvnice češtiny 2 - Tvarosloví, Academia, Praha.

Polívková A. 2007: Naše místní jména a jak jich uživat, Euromedia Group, Praha.

Profous A. 1947: Místní jména v Čechách, I: $A-H$, Česká akademie věd a umění, Praha.

Šimandl J. 2012a: Rod pomnožných proprií, rod v plurálu, rod obecně, „Jazykovědné aktuality” XLIX, s. $124-128$.

Šimandl J. 2012b: Morfologie proprii včera a dnes, [v:] S. Čmejrková, J. Hoffmannová, J. Klímová (red.), Čeština v pohledu synchronním a diachronním. Stoleté kořeny Ústavu pro jazyk český, Univerzita Karlova, Praha, s. 583-591.

Šrámek R. 1999a: Ke gramatickým vlastnostem proprií, [v:] K. Klímová, H. Kneselová (red.), Propria $v$ systému mluvnickém a slovotvorném. Sborník přispěvků z mezinárodní konference „, Onomastika a škola “ konané v Brně ve dnech 10.-11. 2. 1998, Masarykova univerzita, Brno, s. 16-23.

Šrámek R. 1999b: Onomastičnost onomastické gramatiky, [v:] E. Jakus-Borkowa, K. Nowik (red.), Najnowsze przemiany nazewnicze, Energeia, Warszawa, s. 255-260.

Šrámek R. 1999c: Úvod do obecné onomastiky, Masarykova univerzita, Brno.

Šrámek R. 2007a: Beiträge zur allgemeinen Namentheorie, Praesens Verl., Wien.

Šrámek R. 2007b: Transonymizace v propriální nominaci, „Folia onomastica Croatica“ 12-13, s. 499-508 .

Štícha F. et al. 2013: Akademická gramatika spisovné češtiny, Academia, Praha.

Tomescu D. 1998: Gramatica numelor proprii în limba românâ, All Educational, Bucureşti.

Trávníček F. 1951: Mluvnice spisovné češtiny, č. I: Hláskosloví, tvoření slov, tvarosloví, Slovanské nakladatelství, Praha.

Tušková J. M. 2007: Toponyma s deklinaci vzoru kost, [v:] K. Klímová, M. Minářová (red.), Čeština bádání a učení. Sborník z mezinárodni konference uspořádané k 60. výroči založení Pedagogické 
fakulty Masarykovy univerzity a k př́ležitosti životního jubilea prof. PhDr. Přemysla Hausera, CSc., Masarykova univerzita, Brno.

Tušková J. M. 2009: Já, ty, on jezdi do Mělníku či Mělníka?, [v:] P. Mitter (red.), Ty, já a oni v jazyce a v literatuře, sborník z mezinárodni konference, 1. díl - Část jazykovédná, Univerzita Jana Evangelisty Purkyně, Ústí nad Labem, s. 223-227.

Tušková J. M. 2011a: Deklinačni systém femininnich oikonym v češtině. Synchronni pohled na základě Českého národního korpusu, Nakladatelství Lidové noviny, Praha.

Tušková J. M. 2011b: Možnosti korpusů psané češtiny při zkoumání deklinace oikonym, [v:] F. Čermák, K. Kučera, V. Petkevič (red.), Korpusová lingvistika Praha 2011, 2 Výzkum a výstavba korpusů. Nakladatelství Lidové noviny-Ústav Českého národního korpusu, Praha, s. 281-286.

Tušková J. M. 2012: Transonymizace oikonym a jeji projevy v morfologické rovině, „Acta onomastica” LIII, s. 323-333.

Český národni korpus — SYN2000. Ústav Českého národního korpusu FF UK, Praha 2000, http://www. korpus.cz (citováno 24.08.2016).

Český národní korpus — SYN2005. Ústav Českého národního korpusu FF UK, Praha 2005, http://www. korpus.cz (citováno 24.08.2016).

Český národní korpus - SYN2010. Ústav Českého národního korpusu FF UK, Praha 2010, http://www. korpus.cz (citováno 24.08.2016).

Český národni korpus — SYN2015. Ústav Českého národního korpusu FF UK, Praha 2015, online: http://www.korpus.cz (citováno 24.08.2016).

\section{TO THE DESCRIPTION OF GRAMMATICAL ASPECT OF PROPER NAMES} IN CZECH LANGUAGE

\section{SUMMARY}

The contribution summarizes approaches to the description of a grammatical aspect of proper nouns in Czech with reference to already existing descriptions that are contained in onomastic grammars of some European languages. It deals with content delimitation of grammatical description of proper nouns in Czech and specifies it by using the example of oikonyms.

Keywords: onomastic grammar, grammatical features of proper names, morphological aspects of proper names, communication variations 